\title{
Tick Bite-Associated New Disease: Alpha-Gal Allergy
}

\section{Kene Isırığı ile İlişkili Yeni Bir Hastalık: Alpha-Gal Allerjisi}

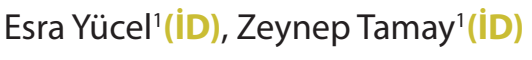 \\ ${ }^{1}$ Division of Pediatric Immunology and Allergy, Department of Pediatrics, Istanbul University Istanbul School of Medicine, Istanbul, Turkey
}

Cite this article as: Yücel E, Tamay Z. Tick bite-associated new disease: Alpha-gal allergy. J Pediatr Inf 2020;14(1):e1-e4.

\section{Abstract}

In recent years, two distinct clinical conditions have been defined due to immunoglobulin E (IgE) antibodies induced by tick bite against Alpha gal, an oligosaccharide found in mammalian meat. The first one is late-onset (after 3-6 hours) IgE-mediated systemic hypersensitivity reactions after red meat consumption, while the second is immediate anaphylaxis during the first minutes of cetuximab infusion. As well as infectious diseases associated with tick bites that can be seen in our country, Alpha gal allergy should be kept in mind, and the awareness of physicians should be increased.

Keywords: Alpha gal, anaphylaxis, food allergy, red meat allergy, tick bite

\section{Introduction}

Seasonal diversity seen in different geographical regions of our country leads to countless diseases associated with tick bites that could be a vector in terms of wildlife. Tick-related pathogens can cause serious and important public health problems in many parts of our country, especially in the tick season.

Disease-carrying ticks in our country can consist both soft (Argasidea- i.e; Ornithodorus) and hard types of ticks (Ixodidaei.e; Ixodes, Hyalomma, Dermacantor). Not just protozoa (Babesiosis) but also rickettsia (Erlichiosis, tick-associated typhus, Mediterranean spotted fever), non-rickettsial bacteria (Lyme Disease, Tick-Associated recurrent fever, Tularemia, Bartonella)
Öz

Son yıllarda memelilerde bulunan bir oligosakkarit olan Alpha gal'e karşı kene ısırığının neden olduğu duyarlılık sonrası gelişen İmmünglobulin $\mathrm{E}$ (IgE) antikorlarına bağıı iki farklı klinik tablo tanımlanmıştır. Bunlardan ilki kırmızı et tüketimi sonrası geç başlangıçıı (3-6 saat sonra) IgE aracılı sistemik aşırı duyarlılık reaksiyonları iken, ikincisi de ilk setuksimab infüzyonunda dakikalar içerisinde görülen anafilaksidir. Kene ısırı̆̆ı ile ilişkili ülkemizde görülebilen enfeksiyon hastalıklarının yanı sıra Alpha gal allerjisi akılda tutulmalı, hekimlerin bu konudaki farkındalıkları arttırılmalıdır.

Anahtar Kelimeler: Alpha gal, anafilaksi, besin allerjisi, kene ısırığı, kırmızı et allerjisi

and viruses (Crimean-Congo Hemorrhagic Fever, Tick-associated Encephalitis) are carried with ticks, which lead to diseases in humans (1). After having been identified for the first time in 2002, Crimean-Congo Hemorrhagic Fever that peaked in the years 2008 and 2009 has an important place due to high mortality rates among all tick-related diseases. Particularly seen in the Central Anatolian region, mean incidence of Crimean-Congo Hemorrhagic Fever has been reported as 900 cases in a year. A total of 9787 cases had been reported between 2002 and 2015, and nearly 500 of these cases died due to this disease (2).

There are various anti-inflammatory, anesthetic and anti-hemostatic factors in tick saliva, which prolong tick's attach

Correspondence Address / Yazışma Adresi

Zeynep Tamay

İstanbul Üniversitesi İstanbul Tıp Fakültesi,

Çocuk Sağlığı ve Hastalıkları Anabilim Dalı,

Çocuk İmmünolojisi ve Allerji Bilim Dalı,

İstanbul-Türkiye

E-mail: eztamay@yahoo.com

Received: 20.02 .2020 
and facilitate feeding. This content causes some immunologic reactions to begin in the host.

Anaphylaxis has been reported following the bite of some types of ticks (Argas reflexus) in Europe. IgE antibodies that develop against the proteins contained in tick saliva are responsible for this reaction $(3,4)$.

An immunoglobulin (lg) E-mediated, unusual hypersensitivity reactionA that presents itself late (4-6 hours) after red meat consumption has been identified in recent years. This clinical picture is different from usual lgE-mediated hypersensitivity reactions since antigenic stimulus occurs against carbohydrate-like galactose-alpha-1,3-galactose (Alpha Gal) epitope not against a protein-like antigen. Sensitivity occurs unexpectedly with tick bite (3). Contrary to expectations, this Ig E-mediated systemic reaction has a late onset.

\section{HISTORY}

Identification of Alpha gal allergy has been fulfilled thanks to various epidemiologic observations. A monoclonal antibody, against Epidermal Growth Factor Receptor (EGFR) to be used in the treatment of metastatic colorectal cancer was first developed in 2004. Anaphylaxis cases developing minutes after the first infusion of the drug has been observed during Cetuximab trials in southeastern states of the United States of America (5). These cases have been shown to carry specific lgE antibodies against the drug prior to drug infusion in studies conducted thereupon, and in the coming years, glycosylation mechanism of Cetuximab has been confirmed to contain $\alpha 1,3-$ galactosyl residues, and it has been discovered that this specific $\lg E$ that develop against Cetuximab essentially develops against the $\alpha 1,3$ galactose oligosaccharide in the Fab region of Cetuximab's heavy chain $(6,7)$.

During the same dates in the southeastern states of the USA, recurrent common urticaria, angioedema and anaphylaxis were seen in individuals participating in outdoor activities, and the common thread in all was the fact that they had all consumed red meat 3-5 hours prior to reactions. Interestingly, specific lgE levels of these patients and concurrently their skin penetration tests with both commercial allergenic extracts and cooked and raw bovine, sheep and pork meat were determined negative (8).

Karl Landsteiner established in 1936 that humans had antibodies against the "B-like" oligosaccharides contained in blood group antigens of non-primate animals (9). The discovery that this antigen has the same structure as Alpha gal and that Alpha gal is present in meat and tissues of non-primate mammals has ensured the most crucial of all clues required to identify these unexplained hypersensitivity reactions (10). Based on the fact that the aforementioned two different clinical findings have been seen in similar geographic regions, researchers have examined Alpha gal sensitivity in the serum of these patients. Researchers have indicated that Alpha gal specific IgE values of the patients were significantly high and that four of the seven types of Alpha gal specific epitopes found in red meat did not disappear by cooking (11).

For the first time in 2009, red meat allergy and tick bite were reported to be linked in an article published in Australia (12). Thereupon, researchers observed that the distribution region of Amblyomma americanum (Lone Star Tick) found in the region where Rocky Mountain Spotted Fever in the USA was seen most frequently and the regions where reactions to red meat and Cetuximab were the same. Detection of Alpha gal specific IgE increase in individuals bitten by this type of ticks put forth the relation between tick bite and red meat (13). Other than the types found in the USA, cases with red meat allergy that develop after bites due to tick types including Ixodes holocyclus from Australia, Ixodes ricinus from Europe, and Ambylomma cajennense from Panama were reported $(12,14,15)$. Alpha gal allergen has been isolated from the gastrointestinal system of Ixodes ricinus type of tick in a study (16). In the USA, primary vector of Lyme disease, Ixodes scapularis ticks, has been shown to not develop specific lgE against Alpha gal (17). Cases with Alpha gal allergy have also been reported in our country. These cases consisted of those bitten by Ixodes ricinus, a dominant tick type from Ordu and Giresun cities located in the Central Black Sea region $(18,19)$.

In a recent study with an 'Apha gal knock out' rat model, subcutaneous administration of tick saliva has been shown to provide sufficient antigenic stimulus for the development of Alpha gal specific lg E, and thus, tick bite has been confirmed to be the most important means for the development of sensitivity in Alpha gal allergy (20). In recent years, having revealed that Alpha gal sensitivity caused by parasites (i.e. helminths) other than ticks has an immunomodulator effect and that it has provided increase in regulatory $T$ ( $T$ reg) cells and decreased allergic response has paved the way to consider that this situation corresponded to "hygiene hypothesis" (21).

In a study performed due to the homologous structure of human blood group antigens and Alpha gal, it has been reported that Alpha gal allergy is seen more commonly in people with $O$ and $B$ blood types specifically containing Anti B antibody (14).

\section{CLINICAL FINDINGS and DIAGNOSIS in ALPHA GAL ALLERGY}

Alpha-Gal allergy results in two distinct clinical findings. One of these is early lgE-mediated systemic hypersensitivity reaction seen within minutes of Cetuximab's first infusion and 
could be fatal. The other is late lgE-mediated systemic reactions that occur as extensive itchiness especially in the palmar region, urticaria and anaphylaxis or gastrointestinal systems like nausea starting within 2-5 hours following red meat consumption. Most patients have a history of tick bites 15 days to 1 month prior to the manifestation of the symptoms. Some cofactors like exercise, cooking of the consumed meat, the amount consumed, and consumption of offal like kidney and spleen may also affect the onset of symptoms. While these patients are expected to show symptoms with all types of red meat, reaction does not occur with other meat types like chicken and fish. Some patients also have higher or lower number of antigens associated with mild symptoms like itchiness and urticaria, which is related to the part of the animal consumed (22).

Late reaction development after red meat consumption is explained with the process of red meat digestion as follows: some time has to pass for Alpha gal to be carried in systemic circulation by chylomicrons and VLDL, and IgE-mediated late reaction starts by the activation of mast cells by Alpha gal carried over VLDL in individuals who has already developed sensitivity with prior tick bite (23).

For diagnosis, either negativity or small (2-4 mm) enduration is detected in skin prick tests performed with red meats like beef, sheep and pork meat themselves or with their commercial extracts. Specific lgE values tested for these allergens are mostly negative and not diagnostic. Skin prick test and intradermal test with Cetuximab and Alpha gal specific IgE identification in blood are more specific tests for diagnosis (4). A study has revealed that detection of Alpha gal specific IgE over $5.5 \mathrm{kU} / \mathrm{L}$ foresees Alpha gal allergy at a rate over $95 \%$. Along with no standard protocol for red meat challenge test to confirm Alpha gal allergy, the patient needs to be monitored for a long time since late reaction is expected (24).

\section{TREATMENT in ALPHA GAL ALLERGY}

Avoiding the culprit food is the most important treatment method in Alpha gal allergy, just as in other food allergies. Absolute avoidance from all red meats and offal is recommended. The patients should be prescribed with adrenalin auto-injector and be taught how to use and when to use it. Desensitization with red meat remains an investigated treatment method for patients that have a hard time adjusting their diet, that are at risk of accidental consumption and wish to consume red meat continuously $(18,25)$. Prevention of patients with Alpha gal allergy being bitten by ticks again can result in a gradual decrease in lgE, and some patients are considered to tolerate red meat in upcoming years in this way (22).

\section{ALPHA GAL ALLERGY and ASSOCIATED SPECIAL SITUATIONS}

\section{Children}

Alpha gal allergy seen mostly in adults have been reported to be encountered in children, as well. In a study conducted in the USA, late allergic reaction after red meat consumption has been identified in children, just as in adults. Geographic distribution and clinical findings are similar to those of the adults, and several patients have received Alpha gal allergy diagnosis during tests carried out for stomach pain that developed after red meat consumption (26).

\section{Vaccines}

Reactions has been reported in patients with Alpha gal allergy immunized with vaccines containing bovine gelatin. Most of these reactions have occurred following Varicella Zoster vaccine (Zostavax) containing hydrolyzed gelatin (27).

\section{Prosthetic Heart Valves}

Just as cases reported to be complicated with acute allergic reaction after bovine or pork-made bioprosthetic valve implantations, there are reported cases with Alpha gal allergy who developed early valve insufficiency and valve deformation. Therefore, there are studies conducted to develop bioprosthetic valve that do not contain Alpha gal $(28,29)$.

\section{Idiopathic Anaphylaxis}

In a study conducted, Alpha gal allergy has been detected in $9 \%$ of the cases with idiopathic anaphylaxis (30). The reasons for these patients to be evaluated as idiopathic anaphylaxis include the late onset of symptoms after red meat consumption and the patient's inability to correlate these symptoms with it, having had no inquiries of tick bite history or the fact that the patient him/herself does not remember this fact. Therefore, Alpha gal allergy must be considered in the differential diagnosis of idiopathic anaphylaxis.

\section{CONCLUSION}

In conclusion, Alpha gal allergy is a newly identified clinical picture with different pathophysiology and different clinical findings and associated special conditions. Owing to the fact that cases have been reported from only one geographical location in our country, the contribution of the vegetation endemic to that region (i.e. hazelnut) and tick population of this region should be investigated. Alpha gal allergy like any other tick-related disease should be kept in mind, and physician awareness regarding this subject should be increased.

Conflict of Interest: No conflict of interest was declared by the authors.

Financial Disclosure: The authors declared that this study has received no financial support. 


\section{References}

1. Inci A, Yıldırım A, Duzcu O, Doganay M, Aksoy S. Tick-borne diseasies Turkey; a review based on one health perspective. PLOS Neglected Tropical Diseases 2015;1-12. [CrossRef].

2. Leblebicioğlu $H$, Ozaras $R$, Irmak $H$, Sencan I. Crimean-Congo hemorrhagic fever in Turkey: Current status and future challenges. Antiviral Res 2016;126:21-34. [CrossRef]

3. Commins SP, Platts-Mills TAE. Tick bites and red meat allergy. Curr Opin Allergy Clin Immunol 2013;13:354-9. '[CrossRef]

4. Steinke JW, Platts-Mills TAE,Commins SP. The alpha-gal story: Lessons learned from connecting the dots. J Allergy Clin Immunol 2015;135:58996.'[CrossRef]]

5. O'Neil BH, Allen R, Spiegel DR, Strinchcombe TE, Moore DT, Berlin DJ, et al. High incidence of cetuximab related infusion reactions in Tenessee and North Carolina and association with atopic history. J Clin Oncol 2007;25:3644-8. [CrossRef]"

6. Maier S, Chung CH, Morse M, Platt-Mills TAE, Townes L, Mukhopadhyay $P$, et al. A retrospective analysis of cross reacting cetuximab lgE antibody and its association with severe infusion reactions. Cancer Med 2015; 4:36-42. '[CrossRefi]"

7. Qian J, Liu T, Yang L, Daus A, Crowley R, Zhou Q. Structural characterization of $\mathrm{N}$-linked oligosaccharides on monoclonal antibody cetuximab by the combination of orhogonal matrix-assisted laser desorption/ionization hybrid quadrupole-quadrupole time-of-light tandem mass spectrometry and sequential enzymatic digestion. Anal Biochem 2007;364:8-18. [CrossRef]]

8. Commins SP, Satinover SM, Hosen J, Mozena J, Borish L, Lewis BD, et al. Delayed anaphlaxis, angioedema or urticaria after consumption of red meat in patients with IgE antibodies specific for galactose-alpha-1,3galactose. J Allergy Clin Immunol 2009;123:426-33. [CrossRef]"

9. Landsteiner $K$. The specificity of serological reactions. Baltimore (MD): Charles C Thomas;1936.

10. Milland J, Sandrin MS. ABO blood group and related antigens, natural antibodies and transplantation. Tissue Antigens 2006;68:459-66. [Crossiefin

11. Apostolovic D, Tran H, Hamsten C, Starkhammar M, Cirkovic Velikovic $T$, van Hage M. Immunoproteomics of processed beef proteins reveal galactose-alpha-1,3-galactose containing allergens. Allergy 2014;69:1308-15. [[ [rossief $]_{1}$

12. Van Nunen SA, O'Connor KS, Clarke LR, Boyle RX, Fernando SL. An association between tick bite reactions and red meat allergy in humans. Med J Aust 2009;190:510-1.'[CrossRef]],

13. Commins SP, James HR, Kelly HA, Pochan SL, Workman LJ, Perzansowski $M S$, et al. The relevance of tick bites to the production of IgE antibodies to the mammalian oligosaccharide galactose-alpha-1,3-galactose. J

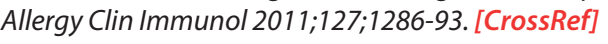

14. Hamsten C, Tran TA, Stackhammar M, Brauner A, Commins SP, PlattMills TA, et al. Red meat allergy in Sweden: association with tick sensitization and B negative blood groups. J Allergy Clin Immunol 2013;132:1431-4. $\overline{\underline{1}}$ Cross $\overline{\text { Ref }}]_{1}$

15. Wickner PG, Commins SP. The first 4 central american cases of delayed meat allergy with galactose-alpha-1,3-galactose positivity clustered among field biologists in Panama. J Allergy Clin Immunol 2014;133(2): 212. [C CrossRefin]"
16. Hamsten $C$, Stackhammar $M$, Tran TA, Johansson $M$, Bengtsson $U$, Ahlen $G$, et al. Identification of galactose-alpha-1,3-galactose in the gastrointestinal tract of the tick Ixodes ricinus: possible relationship with red meat allergy. Allergy 2013;68:549-52. [CrossRef]"

17. Burke G, Wikel SK, Spielman A, Telford SR, McKay K, Kruse PJ. Hypersensitivity to ticks and Lyme Disease risk. Emerg Infect Dis 2005; 11:34-41.

18. Unal D, Coskun R, Demir S, Gelincik A, Colakoglu B, Buyukozturk S. Successful beef desensitization in 2 adult patients with a delayed-type reaction to red meat. J Allergy Clin Immunol Pract 2017;5(2):502-3.

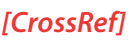

19. Araujo RN, Franco PF, Rodrigues H, Santos LC, McKay CS, Sanhueza $C A$, et al. Amblyomma sculptum tick saliva:alpha gal identification, antibody response and possible association with red meat allergy in

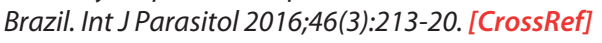

20. McSorley HJ, Hewiton JP, Maizels RM. Immunomodulation by helmint parasites: defining mechanisms and mediators. Int J Parasitol

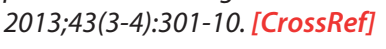

21. Platts-Mills TAE, Schuyler AJ, Hoyt AEW, Commins SP. Delayed anaphylaxis involving IgE to galactose-alpha-1,3- galactose. Curr Allergy Asthma Rep 2015;15(4):512-6. [י [Cross Ref $]_{1}$

22. Commins SP, James HR, Stevens $W$, Pochan $S L$, Land MH, King C, et al. Delayed clinical and ex vivo response to mammalian meat in patients with IgE to galactose-alpha-1,3- galactose. J Allergy Clin Immunol

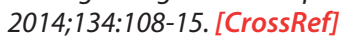

23. Mabelane T, Basera W, Botha M, Thomas HF, Ramjith J, Levin ME. Predictive values of alpha-gal IgE levels and alpha-gal IgE: Total IgE ratio and oral food challenge-proven meat allergy in a population with a high prevalence of reported red meat allergy. Pediatr Allergy Immunol 2018;29(8):841-9. [' CrossRef $]_{1}$

24. Yucel E, Cimen SS, Varol S, Suleymen A, Ozdemir C, Tamay ZU. Red meat desensitization in a child with delayed type anaphylaxis due to alpha gal allergy. Pediatr Allergy Immunol 2019;30(7):771-3. [Cross.

25. Uzunoglu E, Polat E, Oguz ID, et al. Tick bite cases among hazelnut farm workers in Giresun. Cumhuriyet Medical Journal 2017;39(2):4738. $\overline{\underline{i}}$ [rossinef $]_{1}$

26. Kennedy JL, Stallings AP, Platts-Mills TA, Oliviera WM, Workman L, James $H R$, et al. Galactose-alpha-1,3-galactose and delayed anaphylaxis, angioedema, and urticaria in children. Pediatrics 2013;131(5):e1545-52. [Cross Refi]"

27. Mullins RJ, James H, Platts-Mills TA, Commins SP. Relationship between red meat allergy and sensitization to gelatin and galactose-alpha-1,3galactose. J Allergy Clin Immunol 2012;129:1334-42. [CrossRef]

28. Mozzicato SM, Tripathi A, Posthumus JB, Platts-Mills TA, Commins SP Porcine or bovine valve replacement in 3 patients with IgE antibodies to the mammalian oligosaccharide galactose-alpha-1,3-galactose. J Allergy Clin Immunol Pract 2014;2:637-8. [C Cross Ref

29. Naso F, Gandaglia A, Bottio T, Tarzia V, Nottle MB, d'Apice AJ, et al. First quantification of alpha-Gal epitope in current glutaraldehyde-fixed heart valve bioprostheses. Xenotransplantation 2013;20:252-61. [C [ross Ref $]_{1}$

30. Carter MC, Ruiz-Esteves KN, Workman L, Lieberman P, Platts-Mills TAE, Metcalfe DD. Identification of alpha-gal sensitivity in patients with a diagnosis of idiopathic anaphylaxis. Allergy 2018 May;73(5):1131-4. [CrossRef $]_{1}$ 